Підготовка вчителя початкових класів до пропедевтичного викладання основ літературознавства на уроках літературного читання (зображувально-виражальні засоби)

УДК 378.147:373.3.011.3-052+378.016:82

\title{
ПІДГОТОВКА ВЧИТЕЛЯ ПОЧАТКОВИХ КЛАСІВ ДО ПРОПЕДЕВТИЧНОГО ВИКЛАДАННЯ ОСНОВ ЛІТЕРАТУРОЗНАВСТВА НА УРОКАХ ЛІТЕРАТУРНОГО ЧИТАННЯ (зображувально-виражальні засоби)
}

\author{
Валерій Сиротенко \\ кандидат філологічних наук, доцент \\ ДВНЗ «Донбаський державний педагогічний університет» \\ м. Слов’янськ Донецької області, Україна \\ ORCID ID 0000-0003-0000-1532 \\ valerij.s.kram@gmail.com \\ Олена Бондаренко \\ старший викладач Краматорського інституту \\ ПРАТ «Міжрегіональна академія управління персоналом» \\ м. Краматорськ Донецької області, Україна
}

Анотація. Стаття присвячена двоєдиній проблемі: змісту пропедевтичного матеріалу з основ літературознавства на уроках літературного читання в початкових класах і характеру методичної підготовки майбутнього вчителя початкових класів, що викладає шкільний предмет «Літературне читання», до методично правильної й ефективної побудови уроку літературного читання, на якому формуються уявлення про ті чи ті літературознавчі поняття. Ця двоєдність і обумовлює стратегію й тактику вишівського навчального процесу забезпечення належної теоретичної підготовки з основ літературознавства та здійснення всебічної практичної методичної підготовки щодо виконання фахових функцій.

Окреслена мета реалізується на лекційних $\mathrm{i}$ практичних заняттях 3 основ літературознавства та дитячої літератури 3 методикою навчання літературного читання. Розглянуто можливості лекції з елементами бесіди, практичних занять різної тематики, але 3 єдиною умовою: усі завдання повинні носити пошуково-творчий характер, що забезпечить ефективність засвоєння студентами необхідних професійних знань, гарантує їхнє репродуктивно-активне застосування безпосередньо в педагогічній діяльності.

Ключові слова: літературознавча пропедевтика; зображувально-виражальні засоби; епітет; порівняння; символ; персоніфікація; алітерація; анафора; інверсія; еліпсис; риторичні питання та звертання; літературна дидактична гра; евристична бесіда; самостійна робота; вибіркове читання.

Постановка проблеми в загальному вигляді. Якщо перефразувати висловлювання, що у футболі та сільському господарстві розбираються всі, то щось подібне можна сказати і стосовно літератури. Дійсно, пересічний читач, не задумуючись, видасть тривіальну оцінку «сподобалось/не сподобалось» будьякому творові, але на цьому найшвидше і вичерпаються його можливості «літературного критика». Безумовно, для спілкування 3 мистецтвом, зокрема 3 літературою, потрібен відповідним чином підготовлений реципієнт, знання, уміння й навички якого спираються, бодай, на шкільний курс літератури, 
фундамент якого закладається ще в початкових класах. А що стоїть за поняттям «підготовлений читач»? Це передусім особистість, розвинений інтелект, багатий духовний світ, які не з'являються на голому місці, а потребують вдумливого, копіткого, цілеспрямованого формування та виховання. Отже, неймовірно зростає роль самої освіти в найширшому розумінні цього слова, бо «освіта $\epsilon$ найбільш ефективним засобом підвищення життя, найбільш ефективною зброєю в боротьбі з бідністю та різними проявами нетерпимості.

Освіта створює культуру, яка базується на миролюбстві, вона надає молоді й дорослим можливості досягти успіхів в обраній сфері діяльності. Освіта за своєю сутністю може відкрити шляхи для розвитку особистості зокрема та суспільства загалом» [8, с. 6]. Для реалізації подібної якості потрібно багато передумов, серед яких однією з провідних є постать шкільного вчителя сучасної формації. Як наголошує В. Ільман, «саме через його діяльність реалізується державна політика, спрямована на зміцнення інтелектуального і духовного потенціалу нації, розвиток вітчизняної науки i техніки, збереження i примноження культурних надбань» [7, с. 30]. Тому нагальною стає проблема суттєвої видозміни всього процесу підготовки майбутнього вчителя, перетворення вишу із закладу, у якому студент «напаковувався» теоретичним матеріалом, на навчально-виховний заклад, здатний активно впливати на креативні здібності молодої людини, стимулювати іiі до творчого пошуку, мислення новими громадськими та науковими категоріями. I потреба в такому педагогові усвідомлюється всім суспільством: «На сучасному етапі розвитку освіти професійна підготовка та виховання кадрів є одним із вагомих завдань розвитку суспільства. Для ефективного розв'язання нагальних проблем економіки, політики та культури рівень професійної підготовки нового покоління фахівців має відповідати найважливішим вимогам сьогодення» $[8$, с. 8$]$.

У зв'язку з цим постає закономірне питання, а чи готова сама вища школа гарантувати підготовку відповідних спеціалістів, чи виробила вона нові теоретично-методичні підходи щодо формування фахівця нової формації: «Якісна професійна підготовка майбутніх учителів початкових класів потребує нових підходів до питань формування їхньої методичної готовності та компетентності» [7, с. 30]. I якщо Г. Волошина зауважує, що під зрослі вимоги до викладання літературного читання (пропедевтичне ознайомлення з основами літературознавства) ще не розроблена відповідна шкільна методика [4], то це в такій же мірі стосується і стану вишівської методики щодо підготовки вчителя початкових класів до викладання шкільного курсу «Літературне читання». А пам'ятати про це слід повсякчас, бо цей предмет - особливий серед усіх шкільних дисциплін. Адже тільки література здатна безпосередньо виконувати таку важливу суспільну функцію, як формування громадянина, відповідати за розвиток його морально-духовних якостей, за утвердження в кожному індивідові гуманістичних начал і цінностей. I щоб досягти цього, учитель повинен так 
побудувати урок літературного читання, щоб він перетворився на урок-роздум, урок-відкриття, а це можливе тоді, коли кожен твір розкриється перед дитиною у всій його змістово-художній неповторності, своєрідності, коли учень зможе належним чином відчути й усвідомити художньо-естетичну вартість чи то оповідання, чи ліричної поезії. А щоб у класі панувала подібна атмосфера, необхідно так організувати навчально-виховний процес у виші, щоб кожне лекційно-практичне заняття перетворилося на справжню методичну лабораторію, коли студент безпосередньо залучається до таїнств методичного мистецтва фахівця-педагога. Тож у пошуках таких «родзинок» і вбачається актуальність нашої розвідки.

Аналіз останніх досліджень і публікацій. 3 огляду на обрану нами проблематику назвемо низку теоретико-методичних праць, у яких у тій чи тій мірі йдеться про вивчення основ літературознавства в початкових класах на пропедевтичній основі. Їх умовно можна поділити на дві групи.

Перша група - дослідження, у яких безпосередньо подаються методичні рекомендації щодо проведення уроку літературного читання 3 опертям на літературознавчий матеріал. Це статті Г. Гергулі «Літературознавча компетенція - основа літературного розвитку школярів» [5], Л. Іванової «Літературознавча пропедевтика в початковій школі» [6], Т. Петровської «Система роботи над образними засобами твору на уроках літературного читання (порівняння)» [12], О. Фенцик «Методика аналізу ліричного твору на уроках літературного читання» [16]. Оскільки ми далі зупинимося на зображувально-виражальних засобах, то звернімо увагу на статтю Т. Петровської. У ній авторка наголошує на специфіці літературного навчання в початкових класах (поетапність, розгляд матеріалу 3 його наступним розширенням), доречно підкреслює особливості засвоєння молодшими школярами літературознавчих теоретичних понять: «від аналізу конкретного літературного явища - до його осмислення і виходу на теоретичне узагальнення, від роботи з окремим літературним твором - до виявлення істотного, повторюваного в ряді творів» $[12$, с. 7]. Подаються й конкретні методичні поради: як на прикладі того чи того художнього тексту спочатку виробляти в учнів практичні навички знаходити у творі предмети, явища, які порівнюються, осмислювати зображувально-мовні прийоми творення порівняння, а вже потім і формування (на рівні розумових можливостей молодшого школяра) сутності порівняння як одного 3 художніх виражальних засобів. Та разом із тим, варто висловити й одне зауваження.

Поділяючи думку автора, що робота над зображувально-виражальними засобами сприяє розвиткові образного мовлення учнів, не можна погодитися 3 тим, що зображувально-виражальні засоби виконують лише цю функцію: спостереження над зображувально-виражальними засобами «виховує в учнів увагу до вживання слів і дає їм розуміння відтінків його значення» $[12$, с. 5]. Це доволі вузьке розуміння ролі зображувально-виражальних засобів у творі. Їхня вагомість значно глибша і грунтовніша, адже, як один із формальних чинників 

уроках літературного читання (зображувально-виражальні засоби)

структури художнього тексту, вони діалектично пов'язані з реалізацією авторського задуму, власне тими компонентами, які і становлять зміст будьякого твору: тема, ідея, конфлікт, проблематика, пафос. Отже, зберегти єдність змісту i форми в процесі аналізу твору - це найважливіше завдання інтерпретатора (учителя - учнів), бо тільки так буде гарантовано естетичний уплив від спілкування з художнім твором як явищем мистецтва, чому й повинні слугувати уроки літературного читання.

Друга група - це праці, пов'язані з підготовкою власне студента до майбутньої педагогічної діяльності. Тут варто назвати докторську дисертацію А. Ситченка «Теоретико-методичні засади аналізу художнього твору в шкільному курсі літератури» та посібник Г. Волошиної «Особливості уроків читання та літературознавча пропедевтика в початковій школі». Так, А. Ситченко розмірковує над тим, що сприйняття художньої літератури - явище надзвичайно індивідуальне, тому викладач вишу не повинен вимагати від студента повторення висловлених на лекції чи вичитаних у підручнику думок, а привчати до самостійного мислення, уміння застосовувати набуті теоретичні відомості для власного інтерпретування тексту, що потім неодмінно проявиться й у манері спілкування учителя з його учнями: «Засвоєння літератури як виду мистецтва залежить насамперед від індивідуальної здатності відтворювати в уяві основні образні компоненти тексту, пояснювати їхній зміст і значення, виявляти тенденційність, зв'язки між емоційно-смисловими одиницями тексту, що забезпечує його цілісне сприйняття й можливі варіанти інтерпретації, приводить читачів до певних художніх узагальнень» [14, с. 9].

Г. Волошина, спираючись на вимоги чинної програми 3 літературного читання для $2-4$ класів [10], не просто розглядає сутність того чи того літературознавчого поняття, яким повинен оволодіти учень початкової школи, але, відштовхуючись від природи самого літературознавчого терміна, окреслює прийоми роботи щодо вивчення його молодшими школярами. Зокрема стосовно мови художнього твору вона зауважує: «Розуміння колосальної ролі, яку відіграє у творі літературна мова як засіб створення художніх образів, дає потрібне спрямування аналізу словесних виражальних засобів. Вивчати й аналізувати мову художнього твору - по-новому тонше і правильніше розуміти його образиідеї» [4]. А це означає, що під час лекційних, а особливо практичних занять викладач повинен виробляти в студентів здатність сприймати художній твір як цілісний організм, у якому один компонент підпорядкований іншому, а тому i пропонувати такі завдання, щоб, виконуючи їх, студенти набували практичних навичок аналізувати твір в єдності його змісту та форми, привчалися розкривати змістово-художню функцію того чи того зображувально-виражального засобу, щоб потім ці самі здатності формувати і в учнів. Але, як нам видається, і в цьому посібникові недостатньо представлений той методичний арсенал, яким повинен оперувати викладач вишу, готуючи майбутнього фахівця до пропедевтичного викладання основ літературознавства на уроках літературного читання. 
Завершуючи огляд, зазначимо, що й ми неодноразово торкалися проблеми, яка робота повинна проводитися зі студентами факультету підготовки вчителів початкових класів стосовно їхньої професійної підготовки до проведення уроків літературного читання $[1 ; 2 ; 3]$. Основний їхній сенс полягає в тому, що якісна підготовка сучасного вчителя початкових класів, який веде уроки літературного читання, повинна здійснюватися не лише на заняттях із методики навчання літературного читання, а й інших літературознавчих дисциплінах: основи літературознавства, дитяча література.

Формулювання цілей статті. Виявлений стан розв'язання проблеми, що досліджується, дозволяє сформулювати мету власної розвідки:

- продемонструвати можливості лекційних і практичних занять із різних літературознавчих дисциплін щодо планомірного формування професійних якостей майбутнього вчителя, що викладає предмет «Літературне читання»;

- $\quad$ визначити доцільність та ефективність різних методичних підходів залежно від природи того чи того зображувально-виражального засобу, виявленого в художньому творі;

- простежити, як залежно від динаміки (поетапність роботи із зображувально-виражальними засобами в кожному класі) засвоєння відомостей про той чи той зображувально-виражальний засіб варіюються методичні прийоми, до яких звертається вчитель на уроках літературного читання.

Результати дослідження. Розпочинаючи наше дослідження, зауважимо, що його методологічною основою можуть стати міркування А. Кузьминського («Педагогіка вищої школи»), а також окремі положення чинної програми 3 літературного читання. Так, А. Кузьминський пише: «<...> у методах навчання важливо бачити те, що вони є способом руху пізнавальної діяльності студентів; визначають логічний шлях оволодіння знаннями, уміннями й навичками; відіграють роль інструменту обміну інформацією між учасниками навчального процесу; регулюють пізнавальну діяльність студентів; сприяють стимуляції учіння; є способом аналізу й оцінювання навчальної діяльності» [9, с. 265]. Тут важливо підкреслити: саме навчання розуміється не як механічне засвоєння готової інформації, а творчий процес, оснований на взаємодії, взаємообміні думок, пошуково-пізнавальній аналітиці, що і $є$ головною умовою формування професійних здібностей, виховує педагога-креативщика, здатного відповідним чином будувати суб'єкт - суб'єктні взаємини з учнями, стимулюючи їх до вдумливої роботи над художнім твором.

У програмі ж по кожному класі чітко окреслено зміст та якісні характеристики поняття «Мова художнього твору», що дозволяє бачити динаміку оволодіння учнями літературознавчим матеріалом, установлювати глибину пропедевтичного занурення в нього. Так, у другому класі зосереджується увага на переносному та багатозначному вживанні слів (на грунті цього формуються уявлення про епітети, порівняння, метафори без вживання 
термінів); у третьому - закріплюється ця інформація під час роботи над фольклорними творами та творами письменників (пояснюється їхня роль у тексті); у четвертому - з'ясовуються причини авторського вибору слова у творах різних жанрів для діалогів, описів природи, зовнішності персонажів, характеристики героїв, розвиваються уміння використовувати художні засоби у власному мовленні (в описах, розповідях) [10]. Принагідно зауважимо, що визначений програмою обсяг знань зображувально-виражальних засобів носить дещо однобокий характер: переважно відомості подаються щодо тропів, частково - лексичних особливостей. Тож уважаємо, що, готуючи студентів у виші, слід зосередитися й на інших групах зображувально-виражальних засобів - фонетичних і стилістичних фігурах (поетичний синтаксис).

Свого часу ми вказували на певний недолік навчальних планів, за якими ведеться підготовка вчителя початкових класів, бо курс «Основи літературознавства» читається лише для окремої спеціалізації («Англійська мова») i в незначному обсязі. Але саме він стає базовим (із погляду літературознавчої пропедевтики) при вивченні дисципліни «Дитяча література 3 методикою навчання літературного читання».

Безумовно, що на заняттях 3 основ літературознавства (тема «Мова художнього твору») подається вся необхідна інформація про кожну з груп зображувально-виражальних засобів. Тож слід подбати про те, щоб отриманий матеріал одразу переходив із розряду теоретично-пасивного до репродуктивноактивного вже на лекційних заняттях. Наприклад, коли з'ясовуються особливості й зображувально-виражальні функції лексичних засобів (запозичена лексика, неологізми, історизми, архаїзми, діалектизми тощо) доцільно провести лекцію 3 елементами бесіди (студентам заздалегідь дається завдання перечитати новелу М. Хвильового «Я (Романтика)»), щоб обговорити змістово-виражальну роль запозиченого історизму «інсургенти/версальці». Ця бесіда може відбуватися за приблизно таким планом:

1. Яка історична подія змальована в новелі?

2. Яких форм в умовах громадянської війни часто набувало ідеологічне протистояння між прихильниками комуністичної ідеї та їі опонентами?

3. Чи виправдовує герой твору ту жорстокість і безжальність, із якими він віддає накази щодо фізичного знищення «ворогів загірної комуни»?

4. Що означає слово «інсургент»? Коли з'явилося слово «версалець»? Стосовно кого воно вживалося?

5. Наскільки художньо доцільним є вживання даних історичних запозичень у тексті новели?

Як бачимо, питання сформульовані таким чином, щоб у процесі аналізу забезпечити єдність змісту (проблематика твору) та форми його реалізації. Адже, з'ясовуючи семантику названих слів, осмислюючи їхню художню роль, студенти безпосередньо переконаються в естетичній вагомості такого виражального засобу, як лексика, зрозуміють практичну необхідність роботи над лексикою під 
час розгляду будь-якого твору, відчують методичну доцільність проведення подібної роботи на уроці літературного читання.

Ще більші пошуково-творчі можливості відкриваються при проведенні практичних занять. Для них варто запропонувати розгляд поезій В. ЕлланаБлакитного «Після Крейцерової сонати» (https://www.ukrlib.com.ua/books/printit.php?tid=38) та Олександра Олеся «Конвалія» (https://www.ukrlib.com.ua/books/printit.php?tid=5986) і «Воля!? Воля!? Сниться, може?..» (https://www.pysar.net/virsz.php?poet_id=50\&virsz_id=131). Кожна 3 них відзначається багатством різноманітних зображувально-виражальних засобів, тому ми виокремимо лише деякі з них.

До вірша В. Еллана-Блакитного варто звернутися після повторення таких понять, як асонанс, алітерація (фонетичні зображувально-виражальні засоби) та символ як різновид метафори (тропи). Студентам пропонується завдання пошукового характеру: які музичні інструменти виконують роль символів; що означають ці символи; за допомогою якого фонетичного прийому автор передає звучання цих музичних інструментів. Виконання поставлених завдань не лише примусить студентів задуматися над смисловим наповненням лексем: «віоліна» i «фанфари», збагнути, яку роль ці символи відіграють у відтворенні психологічного конфлікту, що переживає ліричний герой (проблема вибору між «громадянською позицією» та «міщанським самозаспокоєнням»: за термінологією 20-х років XX сторіччя - О.Б., В.С.), але й перейнятися мелодикою тексту, почути характерні для віоліни та фанфар звуки, пережити їхній емоційний вплив на почуття людини. Так, перед студентами розкриваються «секрети поетичної творчості» (І. Франко), утверджується розуміння того, із якою відповідальністю повинен ставитися реципієнт (студент $\rightarrow$ учитель $\rightarrow$ учень) до художньої тканини твору, відчувати його естетичну самобутність.

Вірш Олександра Олеся «Воля...» насичений різноманітними стилістичними фігурами (риторичні звертання й питання, інверсія, еліпсис). Отже, важливо не просто визначити ту чи ту фігуру, а розкрити іiї змістовохудожнє навантаження. Щоб студенти краще засвоїли, яку функцію в тексті виконує еліпсис, доречно запропонувати провести стилістичний експеримент (це завдання можуть успішно виконувати й учні початкових класів) - усі односкладні («Чом так тихо на селі?») та неповні («Воля на землі») речення реконструювати в повні двоскладні, а потім зіставити емоційне напруження авторського й отриманого варіантів. Зрозуміло, що Олесів текст відзначається вибуховістю, схвильованістю, занепокоєнням тощо. Тож коли це буде констатовано, слід пояснити, кому належать ці переживання, що викликало подібний емоційно-психічний стан людини. У такий спосіб студентам ще і ще раз буде доводитися істина - формальний чинник у творі ніколи не існує сам по собі, він обов'язково, з одного боку, обумовлений, а 3 іншого - покликаний увиразнювати зміст твору, підкреслювати його конфліктно-проблемне або 
Підготовка вчителя початкових класів до пропедевтичного викладання основ літературознавства на уроках літературного читання (зображувально-виражальні засоби)

ідейно-пафосне наснаження, тобто над розкриттям цієї діалектичної взаємозалежності повинен працювати й учитель на уроках літературного читання.

У поезії «Конвалія» можна виділити приклади всіх видів зображувальновиражальних засобів: фонетичні (звуконаслідування завдяки алітерації шиплячих та свистячих): «чорніють, сіріють усюди // Ворони, змії та 3 каменю скелі»; лексичні (емоційно-пестлива лексика): «пестощі вітру летючого», «квітоньки гаю пахучого»; тропи (епітети, символи): «кімната пустельна сіріла», «чорніють, сіріють усюди // Ворони, змії та з каменю скелі»; стилістичні фігури (інверсія, анафора, риторичні питання та звертання): «кімната пустельна», «Де ж тії... // Де ж тії...», «О, не одна ти не в рідній оселі // Квітко!» [11]. Тому до нього доречно звернутися на узагальнюючому етапі практичного заняття, а саму роботу, щоб надати академічній атмосфері певної емоційності, провести у вигляді гри «Хто більше?» - знайти якомога більше різноманітних виражальних засобів і пояснити їхню змістово-художню роль. Уважаємо, що елемент гри не лише надасть заняттю емоційної родзинки, а й продемонструє студентам ефективність цього методичного прийому, який з успіхом можна застосовувати в різних навчальних ситуаціях у початкових класах.

Навчальна дисципліна «Дитяча література 3 методикою навчання літературного читання» підсумовує літературно-методичну компоненту всього навчального процесу. 3 огляду на це робота спрямовується на закріплення, поглиблення й удосконалення набутих теоретичних відомостей про зображувально-виражальні засоби, а на грунті цього формуються методичні знання, уміння методично правильно організовувати пропедевтичне вивчення літературознавчих понять. А це диктує й нові підходи до проведення лекційнопрактичних занять із цього курсу.

По-перше, зростає роль самостійної роботи, бо «в сучасному постійно мінливому світі важливого значення набуває підготовка студентів до самоосвітньої діяльності, тому наразі у вищій школі особлива увага акцентується на організації їхньої самостійної роботи, уміння творчо опрацьовувати інформацію...» [15, с. 128]. У цьому разі студентам надається можливість самостійно проаналізувати запропонований художній твір, узятий із чинних літературних читанок (тут перевіряються не лише знання щодо основ літературознавства, шляхів аналізу художнього твору, а й специфіки дитячої літератури), а потім запропонувати фрагмент уроку 3 його методичним обгрунтуванням, на якому відпрацьовується пропедевтичне вивчення літературознавчих понять.

Для прикладу розглянемо поезію П. Тичини «Хор лісових дзвіночків», яка вивчається у четвертому класі $[13$, с. 111]. Ми не будемо здійснювати змістовохудожній аналіз вірша з погляду специфіки дитячої літератури, бо це не $\epsilon$ завданням нашої розвідки, але констатуємо, що твір містить звуконаслідування (фонетичні зображувально-виражальні засоби), персоніфікацію, епітети (тропи), 
інверсію та анафору (стилістичні фігури), емоційно-забарвлену лексику (лексичні). 3 урахуванням цього й буде здійснюватися пошуково-методична робота: академічна група розбивається на чотири підгрупи, кожна з яких отримує своє методичне завдання. Це урізноманітнить форми роботи на практичному занятті, дозволить розглянути значну частину дидактичного матеріалу (різні групи зображувально-виражальних засобів) та забезпечить пошуководискусійну атмосферу, бо кожна з підгруп буде відстоювати свої пропозиції, аргументувати їх.

Так, «фонетисти» повинні розкрити перед учнями звукову палітру тексту, запропонувавши дітям підібрати відповідні музичні інструменти, ілюструючи свій вибір відповідними цитатами 3 вірша (учитель (студент) узагальнить учнівські відповіді коментуванням, що «мелодика твору» досягається завдяки частому повторюванню сполучень приголосних [дз], [д], [т]). У такий спосіб молодшим школярам доноситься сутність поняття алітерація без використання самого терміна.

«Лексикологи» можуть запропонувати гру «Лінгвістичний мікроскоп». Зауважимо, що використання гри як методичного прийому особливо виправдане в початкових класах, бо, як уважає Г. Геруля, завдяки використанню гри зростає навчальна ефективність уроку, бо літературні ігри «значно полегшують засвоєння та усвідомлення літературознавчих понять» [5, с. 8]. Учитель (студент) запропонує дітям охарактеризувати емоційне наповнення тексту, знайти в ньому слова, які надають йому подібного наснаження, i здійснити «лексичну реконструкцію» - замінити слова з пестливим значенням на звичайні, а відтак порівняти обидва варіанти. Отже, молодші школярі не лише вдумливо ще раз перечитають твір, знайдуть його лексичні домінанти, але й зрозуміють, що різна лексика має різні виражальні можливості.

Група «Тропи» організовує роботу 3 вибіркового читання тексту («Зачитати рядки, у яких описано лісові дзвіночки. Кого вони нагадують? Чому саме так лісові квіти змалював поет?», «Знайти рядки, у яких дається характеристика природних явищ. Чиї і які почуття вони передають?» «У прямому чи переносному значенні вжито всі відзначені слова?»). Щоб поставити перед учнями подібні завдання, сам учитель (студент) повинен розуміти асоціативну природу тропів, а відтак спрямовувати й учнівське мислення в подібному руслі.

Група «Стилістичні фігури» спочатку розробляє питання для евристичної бесіди (Які члени речення існують в реченні? У якій послідовності вони можуть розташовуватися в реченні? Чи можна при конструюванні висловлювання вдаватися до повторення одних і тих самих слів? Чим можна виправдати таке повторення?), щоб потім заповнити таблицю «Особливості побудови тексту вірша „Хор лісових дзвіночків”»: 
Підготовка вчителя початкових класів до пропедевтичного викладання основ літературознавства на уроках літературного читання (зображувально-виражальні засоби)

\begin{tabular}{|c|c|c|c|}
\hline $\begin{array}{l}\text { № } \\
\text { Пா/II }\end{array}$ & Фрагмент тексту & $\begin{array}{c}\text { У чому особливість } \\
\text { побудови речення чи } \\
\text { словосполучення }\end{array}$ & Мій коментар \\
\hline 1 & $\begin{array}{l}\text { Ми дзвіночки, } \\
\text { Лісові Дзвіночки, } \\
\text { славим день... }\end{array}$ & \begin{tabular}{lc} 
Між & \multicolumn{1}{c}{ головними } \\
членами речення \\
другорядні (інверсія)
\end{tabular} & \\
\hline 2 & $\begin{array}{l}\text {.. дзвоном зустрічаєм: } \\
\text { день! } \\
\text { День. }\end{array}$ & $\begin{array}{l}\text { Повторення одного й } \\
\text { того ж слова в різних } \\
\text { рядках (анафора) }\end{array}$ & \\
\hline 3 & $\begin{array}{l}\text { Хай по полю, } \\
\text { золотому полю, } \\
\text { ляже тінь. } \\
\text { Хай схитнеться } \\
\text { — жито усміхнеться: } \\
\text { тінь! } \\
\text { Тінь. }\end{array}$ & $\begin{array}{l}\text { Повторення однакових } \\
\text { слів у різних рядках } \\
\text { (анафора), присудок } \\
\text { стоїть перед підметом } \\
\text { (інверсія) }\end{array}$ & \\
\hline
\end{tabular}

Така робота формуватиме в учнів навички зосереджувати увагу на порядкові слів у реченні, наявності словесних повторів (це $є$ підгрунтям для засвоєння сутності окремих стилістичних фігур), а вчитель (студент) удосконалюватиме навички застосування різних методичних форм роботи щодо вивчення літературознавчих понять на пропедевтичному рівні.

Висновки 3 дослідження і перспективи подальших розвідок у цьому напрямі. Проведені спостереження дозволяють стверджувати, що оволодіння молодшими школярами комплексом літературознавчих понять - це вагомий крок до здатності сприймати художній твір у його змістовій i художній своєрідності, відчувати естетичну природу тексту, поціновувати його митецьку вартість. І ці знання та вміння учень отримає лише від учителя, який сам повинен бути високоякісним фахівцем у цій справі. Тим-то підготовка студента у виші до успішного виконання своїх професійних обов'язків повинна носити систематичний, цілеспрямований і поетапний характер. Отже, і порушена нами проблема повинна знайти своє подальше продовження:

- $\quad$ шляхи формування в студентів фахових умінь і навиків, необхідних для вивчення інших літературознавчих понять на уроках літературного читання; - визначити методичні підходи до організації самостійної роботи студентів, спрямованої на засвоєння літературознавчих знань;

- виявлення методичних особливостей щодо пропедевтичного вивчення основ літературознавства в початкових класах із використанням інтерактивних технологій.

\section{СПИСОК ВИКОРИСТАНИХ ДЖЕРЕЛ}


Підготовка вчителя початкових класів до пропедевтичного викладання основ літературознавства на уроках літературного читання (зображувально-виражальні засоби)

1. Бондаренко, О.Е. і Сиротенко В.П. (2015). Врахування жанрової природи творів під час вивчення лірики в початкових класах. Початкова школа, 5, 51-54.

2. Бондаренко, О.Е., і Сиротенко, В.П. (2017). Практика застосування різноманітних шляхів аналізу художнього твору на уроках літературного читання. Професіоналізм педагога: теоретичні й методичні аспекти, 5 (1), 77-89.

3. Бондаренко, О.Е. і Сиротенко, В.П. (2013). Формування у студентів факультету підготовки вчителів початкових класів навичок літературознавчого аналізу художнього твору при вивченні курсу «дитяча література». Лінгводидактика: теорія, методика, досвід, 4, 1621.

4. Волошина, Г.П. (2011). Особливості уроків читання та літературознавча пропедевтика у початковій школі. Посібник для студентів та учителів початкових класів. Взято 3 https://dspace.udpu.edu.ua/jspui/bitstream/6789/325/1/Osoblyvosti_urokiv_chytannia.pdf

5. Геруля, Г. (2010). Літературознавча компетенція - основа літературного розвитку школярів. Початкова школа, 3, 7-10.

6. Іванова, Л. (2006). Літературознавча пропедевтика в початковій школі. Початкова освіта, 8,3 .

7. Ільман, В. (2011). Деякі аспекти вдосконалення професійної підготовки вчителя початкової школи: сучасні тенденції. Рідна школа, 1-2, 30-32.

8. Кнодель, Л.В. (2008). Педагогіка вищої школи. Київ, Україна: Вид. Паливода А.В.

9. Кузьминський, А.І. (б.д.). Педагогіка вищої школи. Київ, Україна: Знання.

10. Літературне читання. Програма для 2-4-х класів ЗНЗ. Взято 3 https://osvita.ua/school/program/program-1-4/57055/

11. Олесь, О. https://www.ukrlib.com.ua/books/printit.php?tid=5986

12. Петровська, Т. (2013). Система роботи над образними засобами художнього твору на уроках літературного читання (порівняння). Початкова школа, 4, 5-7.

13. Савченко, О.Я. (2015). Літературне читання. 4 клас. Київ, Україна: Видавничий дім «Освіта».

14. Ситченко, А.Л. (2005). Теоретико-методичні засади аналізу художнього твору в шкільному курсі літератури. (Автореф. дис. д-ра пед. наук). Київ, Україна.

15. Туркот, T.І. (2011). Педагогіка вищої школи. Київ, Україна: Кондор.

16. Фенцик, О. (2012). Методика аналізу ліричного твору на уроках літературного читання. Початкова школа, 12, 19-23.

\title{
ПОДГТОВКА УЧИТЕЛЯ НАЧАЛЬНЫХ КЛАССОВ К ПРОПЕДЕВТИЧЕСКОМУ ПРЕПОДАВАНИЮ ОСНОВ ЛИТЕРАТУРОВЕДЕНИЯ НА УРОКАХ ЛИТЕРАТУРНОГО ЧТЕНИЯ (изобразительно-выразительные средства)
}

\author{
Валерий Сиротенко \\ кандидат филологических наук, доцент \\ ГВУЗ «Донбасский государственный педагогический университет», \\ г. Славянск, Украина \\ ORCID ID 0000-0003-0000-1532 \\ valerij.s.kram@gmail.com \\ Елена Бондаренко \\ старший преподаватель Краматорского института
}

(ㄱ ДВНЗ «Донбаський державний педагогічний університет» 
Підготовка вчителя початкових класів до пропедевтичного викладання основ літературознавства на уроках літературного читання (зображувально-виражальні засоби)

\title{
ЧАО «Межрегиональная академия управления персоналом»
}

\section{г. Краматорск, Украина}

Аннотация. В статье рассматривается двуединая проблема: 1 - содержание пропедевтического материала по основам литературоведения на уроках литературного чтения в начальных классах, 2 - характер методической подготовки будущего учителя начальных классов, ведущего предмет «Литературное чтение», с точки зрения методически правильного и эффективного построения урока литературного чтения, на котором формируются представления о тех или иных литературоведческих понятиях. Это двоединство и обуславливает стратегию и тактику подготовки по основам литературоведения и осуществление всесторонней методической подготовки относительно выполнения профессиональных функций.

Указанная цель реализуется на лекционных и практических занятиях по основам литературоведения и детской литературы с методикой обучения литературного чтения. Рассматриваются возможности лекции с элементами беседы, практических занятий различной тематики, но с единым условием: все задания должны носить поисково-творческий характер, что обеспечит эффективность усвоения студентами необходимых профессиональных знаний, гарантирует их репродуктивно-активное применение непосредственно в педагогической деятельности.

Ключевые слова: литературоведческая пропедевтика, изобразительно-выразительные средства, эпитет, сравнение, символ, персонификация, аллитерация, анафора, инверсия, эллипсис, риторические вопрос и обращение, литературная дидактическая игра, эвристическая беседа, самостоятельная работа, выборочное чтение.

\section{PRIMARY SCHOOL TEACHER TRAINING TO PROPAEDEUTICAL TEACHING BASIS OF LITERATURE IN LITERARY READING LESSONS (figurative and expressive means)}

\author{
Valerii Syrotenko \\ Candidate of Philological Sciences, Associate Professor \\ SHEE "Donbas State Pedagogical University" \\ Sloviansk, Ukraine \\ ORCID ID 0000-0003-0000-1532 \\ valerij.s.kram@gmail.com \\ Olena Bondarenko \\ Senior Lecturer \\ Kramatorsk Institute of \\ Private Higher Education Institution \\ "Interregional Academy of Personnel Management" \\ Kramatorsk, Ukraine
}

\begin{abstract}
The article is devoted to a twofold problem: 1 - the content of propaedeutic material on the basis of literary studies in the lessons of literary reading in primary school, 2 - the nature of the methodological training of the future primary school teacher, teaching the school subject "Literary Reading", to methodologically correct and efficient organizing of Literary Reading lesson where the understanding of certain literary concepts is formed. The relevance of the problem is due primarily to the fact that in Literary Reading lessons literary concepts are assimilated in the propaedeutic level that requires the teacher to master specific methodological techniques and forms of organization of
\end{abstract}




\section{В. СИРОТЕНКО, О. БОНДАРЕНКО}

Підготовка вчителя початкових класів до пропедевтичного викладання основ літературознавства на уроках літературного читання (зображувально-виражальні засоби)

the lesson. In this regard, the future primary school teacher should be trained at the university. That is, the higher educational institution should provide the proper theoretical training on the basics of literary studies and equip the future teacher with deep and comprehensive practical methodological skills, skills for performing professional functions. To do this, at the disposal of teachers there are several academic disciplines, including the courses "Basics of Literary Studies" and "Children's Literature with the Methodology of Literary Reading". At the same time, it should be ensured that both lecture and seminars are as active as possible and have the creative nature which inwardly corresponds to the nature of the fiction itself as a type of art, the perception of which has an obvious individual and interpretive character.

The course "Basics of Literary Studies" is fundamental because it reveals the peculiarities of a particular literary phenomenon, including figurative and expressive means. In order to avoid the presentation of bare theory, to activate students' thinking, the lecture is supplemented with the elements of the conversation, which not only contributes to more conscious mastering of important literary positions (lexical figurative and expressive means), but also clearly demonstrates to students the effectiveness of combining different types of educational activities in the lesson.

Significant search and creative possibilities are opened while conducting seminars (the poems of V. Ellan-Blakytnyi "After the Kreutzer Sonata", Oleksandr Oles "The Lily of the Valley", "Freedom!? Freedom!? Maybe dreaming...?" are proceeded). In the verse of V. Ellan-Blakytnyi, assonance, alliteration (phonetic figurative and expressive means), symbols as a kind of metaphor are defined. To do this, the tasks of the search character are done, and the character of the text sound is determined when it is about various musical instruments (violin, fanfare). A similar task asserts the understanding of the responsibility of the recipient (student $\rightarrow$ teacher $\rightarrow$ learners) to the artwork of a piece of literature, to feel its aesthetic identity.

In the verse of Oleksandr Oles "Freedom ...", stylistic figures (rhetorical questions and appeals, inversion, ellipsis) are first defined, and then a stylistic experiment is performed, where single-ended and incomplete sentences are replaced by two-complex, to match both variants and determine the nature of the emotional tension of each of them. In a similar way, it is emphasized that the formal factor in the work never exists in itself, it is obligatory, on the one hand, conditioned, and on the other hand, it is intended to express the content of the work, to emphasize its conflict and problematic or ideological and pathetic inspiration. So the teacher must work on disclosing this dialectical interdependence at the lessons of literary reading.

Study of the poetry "The Lily of the Valley" is performed in the form of the game "Who is more?" (all groups of figurative and expressive means are determined). Due to this the lesson acquires special emotional excellence, as well as students are convinced of the effectiveness of this methodological approach, which can be successfully applied in different educational situations at primary school.

The discipline "Children's Literature with the Methodology of Literary Reading" summarizes the literary and methodical component of the entire educational process. In view of this, the work is aimed at consolidating, deepening and improving the acquired theoretical information about figurative and expressive means (the role of independent work is growing), and on the basis of this methodological knowledge, the ability of methodically correct organization of propaedeutic study of literary concepts is formed. Thus, in the seminars, the poem of P. Tychyna "Choir of Forest Bells" (studied in the 4th form) is analyzed. The academic group is divided into four subgroups (the number of groups of figurative and expressive means), each of which performs its task: alliterations, personification, epithets, inversion, anaphora, features of vocabulary ("Lexical Microscope") are determined. At the same time, each group develops a fragment of the plan of the lesson, in which it offers its own methodology of working with students to clarify the revealed artistic peculiarities. This not only teaches students to carry out analytical and research work, but to conduct a discussion, to defend and argue the proposed methodological techniques and forms of work. 


\section{В. СИРОТЕНКО, О. БОНДАРЕНКО}

Підготовка вчителя початкових класів до пропедевтичного викладання основ літературознавства на уроках літературного читання (зображувально-виражальні засоби)

Key words: literary propaedeutics, figurative and expressive means; epithets; comparisons; metaphor; symbol; personification; alliteration; anaphora; inversion; ellipsis; rhetorical questions and appeals; literary didactic game; heuristic conversation; independent work; selective reading.

\section{REFERENCES (TRANSLATED AND TRANSLITERATED)}

1. Bondarenko, O.E. \& Syrotenko, V.P. (2015). Taking into account genre nature of the literary works while learning lyric. Pochatkova shkola, 5, 51-54.

2. Bondarenko, O.E. \& Syrotenko, V.P. (2017). The practice of implementing various ways of analyzing fiction works in Literary Reading lessons. Profesionalizm pedahoha: teoretychni y metodychni aspekty, 5 (1), 77-89.

3. Bondarenko, O.E. \& Syrotenko, V.P. (2013). Developing primary school teachers' training faculty students' skills of literary analysis of fiction works while studying the course "Children Literature". Linhvodydaktyka : teoriia, metodyka, dosvid, 4, 16-21.

4. Voloshyna, H.P. (2011). Features of Reading lessons and literary studies propaedeutic in primary school. Retrieved from https://dspace.udpu.edu.ua/jspui/bitstream/6789/325/1/Osoblyvosti_urokiv_chytannia.pdf

5. Herulia, H. (2010). Literature Competence. Pochatkova shkola, 3, 7-10.

6. Ivanova, L. (2006). Literature studies propaedeutic in primary school. Pochatkova osvita, $8,3$.

7. Ilman, V. (2011). Some aspects of improving primary school teachers' professional training. Ridna shkola, 1-2, 30-32.

8. Knodel, L.V. (2008). Pedagogy of higher educational institutions. Kyiv, Ukraine: Vyd. Palyvoda A.V.

9. Kuzmynskyi, A.I. (n.d.). Pedagogy of higher educational institutions. Kyiv, Ukraine: Znannia.

10. Literary Reading: Curriculum for forms 1-4. Retrieved from https://osvita.ua/school/program/program-1-4/57055/

$\begin{array}{llll}\text { 11. Oles, O. } & \text { (n.d.). } & \text { Lily. } & \text { Retrieved }\end{array}$ https://www.ukrlib.com.ua/books/printit.php?tid=5986

12. Petrovska, T. (2013). The system of working on figurative means of fiction works in Literary Reading lessons (comparison). Pochatkova shkola, 4, 5-7. «Osvita».

13. Savchenko, O. Ia. (2015). Literary Reading. Form 4. Kyiv, Ukraine: Vydavnychyi dim

14. Sytchenko, A.L. (2005). Theoretical and methodological foundations of analyzing fiction works in school course of literature. (Extended abstract of Doctoral dissertation). Kyiv, Ukraine.

15. Turkot, T.I. (2011). Pedagogy of higher educational institutions. Kyiv, Ukraine: Kondor.

16. Fentsyk, O. (2012). Methodology of analyzing lyric work in Literary Reading lessons. Pochatkova shkola, 12, 19-23.

Матеріали надійшли до редакції 26.11.2018 p. 